\title{
SATISFACTION OF MEDICAL STAFF IN PRIMARY HEALTH CARE OF SUMADIJA DISTRICT
}

\author{
Svetlana Radevic1, Natasa Mihailovic ${ }^{2}$, Sanja Kocic ${ }^{1,2}$, Snezana Radovanovic ${ }^{1,2}$, Mirjana Milosavljevic ${ }^{1,2}$, \\ Sandra Zivanovic ${ }^{3}$ and Svetlana Ristic ${ }^{4}$ \\ IFaculty of Medical Sciences, Kragujevac, Serbia \\ 2Institute of Public Health, Kragujevac, Serbia \\ ${ }^{3}$ Health Center, Kragujevac, Serbia \\ ${ }^{4}$ Institute of Oncology and Radiology of Serbia, Belgrade, Serbia
}

\section{ЗАДОВОЉСТВО ЗАПОСЛЕНИХ У ЗДРАВСТВЕНИМ УСТАНОВАМА ПРИМАРНЕ ЗДРАВСТВЕНЕ ЗАШТИТЕ ШУМАДИЈСКОГ ОКРУГА}

\author{
Светлана Радевић', Наташа Михаиловић2, Сања Коиић,2, Снежана Радовановић1,2, Мирјана Милосављевић1,2, \\ Сандра Живановић ${ }^{3}$, Светлана Ристић ${ }^{4}$ \\ I Факултет медииинских наука, Крагујеваи \\ ${ }^{2}$ Институт за јавно здравље, Крагујевач \\ ЗДом здравља, Крагујеваи \\ ${ }^{4}$ Институт за онкологију и радиологију Србије, Београд
}

\section{ABSTRACT}

Objective. The aim of this study was to evaluate different aspects of job satisfaction among employees as well as to evaluate the overall job satisfaction in health care institutions of the primary health care level in Sumadija district.

Methods. Employee satisfaction survey was conducted in 10 primary health facilities in Sumadija district. We conducted a one-day survey of 1273 employees, using a uniform, anonymous questionnaire developed by the Ministry of Health of the Republic of Serbia within the program of improvement of the quality of health care facilities.

Results. The data we obtained show that a little less than a half of the employees in healthcare institutions of the Republic of Serbia were satisfied with the work they performed. The results of logistic regression showed that, among the factors examined, the following had a statistically significant impact on the assessment of job satisfaction: adequacy of work equipment, possibility of professional development, support by superiors, comparison of satisfaction of 5 years ago and now.

Conclusion. Job-related experience and satisfaction of the employees indicate the need for placement of employee satisfaction as a priority in the process of improving the quality of the health care system.

Keywords: medical staff; personal satisfaction; job satisfaction; primary health care; Serbia.

\section{INTRODUCTION}

Job satisfaction is characterized by how employees feel about their occupations and different aspects of their professions (1). Job satisfaction of employees in health care institutions is a very important parameter that affects the quality of health care (2). Job satisfaction among health-care workers acquires significance for the purpose

\section{САЖЕТАК}

Циљ. Истраживање је имало за ичиљ да проиеени задовољство запослених различитим аспектима посла, као и да да̂ општу оцену задовољства послом у здравственим установама примарног нивоа здравствене заштите у Шумадијском округу.

Метод. Истраживање је спроведено као студија пресека која је укључила 1.277 запослених у десет здравствених установа примарног нивоа здравствене заштите Шумадијског округа коришћењем униформног, анонимног упитника који је креирало Министарство здравља Републике Србије у оквиру Програма унапређење квалитета рада здравствених установа.

Резултати. Подации које смо добили показују да је незнатно мање од половине запослених у здравственим установама Републике Србије задовољно послом који обавља. Резултати логистичке регресије показују да статистички значајан утииај на оцену задовољства послом имају следећи испитивани фактори: адекваност опреме за рад, могућност професионалног развоја, подрика претпостављених, поређење задовољства између стана од пре пет година и садашњег.

Закључак. Доживљај посла и задовољство запослених указују на то да у процесу унапређења квалитета здравственог система задовољство запослених има приоритетно место.

Кључне речи: медицинско особље; лично задовољство; задовољство послом; примарна здравствена заштита; Србија.

of maximization of human resource potential (3). The position of human resource in the health care system is unique, in the sense that unlike any other sector, the human contact is essential for patient's care. The job satisfaction of health-care workers has a positive relationship with patients' satisfaction, and plays a role in 
the continuity of care (4). Therefore, the health care provider's demands for personal development and job satisfaction have to be recognized as quality indicators (5).

Job satisfaction is defined in different ways, but it is actually the result of subjective experience of work through its various aspects and features. Each of these aspects: structural, communicational, motivational, organizational, influences the total job satisfaction. Every employee has certain expectations with respect to the work performed, and the level of achievement of these expectations determines the level of job satisfaction (6). Through their work, people strive to achieve: economic stability, identity and the development of one's personality, status and prestige in society, self-fulfillment, independence, creativity and social interaction. Through their work employees wants to develop as a person, use and develop one's talents and skills, work and achieve results and success that will be identified (2). Besides, the job involves not only job performance, but also the interaction with colleagues, managers, compliance with the rules and policies of the organization, achieving standards of performance, as well as life in the working conditions which are often not ideal.

Job satisfaction decreases employee turnover, absenteeism, and the number of thefts at work, which in turn reduces costs. Job satisfaction is directly related to the nature of work, the quality of organization and the working surroundings. Not only does job satisfaction influence good employee performance, but it also keeps good employee health and endurance (4). Satisfaction is a measurable category and it can be assessed by summarizing the impact of different elements: motivation, communication, organization of work, working conditions, the output, the need for change, financial compensation $(7,8)$. Employees can be happy with some aspects of the job and, at the same time, dissatisfied with other aspects, but for the management of any organization it is very important to identify those aspects and what can be done in terms of improving the overall job satisfaction (9).

Human resources management in health care institutions is an extremely difficult and important task that managers perform with no adequate data and information, especially when it comes to job satisfaction and work motivation of employees. Understanding the problems of job satisfaction is essential to improve the organization of work, business culture and climate, reward system, promotion system, and so on. This applies to health care institutions, perhaps more than for other types of institutions, because those employees have the greatest possible responsibility in their work. Research of employee satisfaction provide the basis for defining the concept of motivation, recognition of needs and their level of satisfaction in the organization and the basis for the actions and measures aimed to improve employee satisfaction. Measuring of job satisfaction is also a key condition to be achieved in improving the quality of health care (10).

The purpose of this study was to evaluate the satisfaction with different aspects of work among employees as well as the general assessment of job satisfaction in health care institutions of the primary health care level in Sumadija district.

\section{METHODS}

Data for this study come from a cross-sectional survey. An employee satisfaction survey was conducted in 10 health facilities of Sumadija district: 7 health centers, Department of Dentistry, Institute for Emergency Medical Services, Department of Occupational Health. It was conducted as a one-day survey, through a uniform, anonymous questionnaire developed by the Ministry of Health of the Republic of Serbia under the program for improving the quality of health care facilities.

The questionnaire of employee satisfaction consisted of eight issues. We regarded 7 of them as independent variables: type of occupation, manager functions, working conditions, professional development, relationship with the senior staff, interpersonal relations and cooperation with colleagues, as well as the willingness to change jobs. General job satisfaction was treated as a dependent variable.

For the analysis of the data obtained, the methods of descriptive statistics were used: Chi-square $(\chi 2)$ test to compare the differences in the frequency of categorical variables, while the influence of a number of independent variables was tested by using logistic regression.

From the base sample, which consisted of 1144 respondents, a sample of 706 respondents was formed for the purposes of logistic regression. The sample included the employees who rated their current job satisfaction as either satisfied or dissatisfied. By eliminating those respondents who rated their job satisfaction as neither satisfied nor dissatisfied and compressing the categories very satisfied and satisfied into satisfied as well as dissatisfied and very dissatisfied into dissatisfied we applied the logistic regression. Data processing was performed in SPSS 19 for Windows. $p$ values $p<0,05$ were considered as statistically significant. The research results are presented in tables and graphs.

\section{RESULTS}

In total, 1273 questionnaires were distributed and 1144 questionnaires (response rate: 89.9\%) were completed and returned. The distribution of employees according to the profile shows that $81.7 \%$ of employees are health workers, $3.6 \%$ are the health associates, $7.5 \%$ are administrative workers and $7.2 \%$ are technical workers. Out of the total number of employees, $12.4 \%$ were managers and, as expected, these employees were significantly more 
satisfied with their work in relation to the employees who were not managers $\left(\chi^{2}=22.195, \mathrm{df}=4, \mathrm{p}=0.000\right)$. The highest percentage of the satisfied was among the administrative workers (43.4\%), while health associates were the most dissatisfied (33.3\%). There was a statistically significant difference in job satisfaction in relation to the profile of employees $\left(\chi^{2}=23.584, \mathrm{df}=12\right.$, $\mathrm{p}=0.023$ ) (Table 1).

Answers to the questions relating to the working conditions in the workplace showed a high degree of employee dissatisfaction with the adequacy of work equipment in service. Somewhat less than a third of the respondents $(31.1 \%)$ were dissatisfied and very dissatisfied (Figure 1). Slightly more than half of employees $(51.8 \%)$ were satisfied with the interpersonal relationships in the workplace, while a significantly higher percentage of employees were satisfied with the cooperation with colleagues (70.5\%) (Table 2). 38\% of respondents were satisfied with the possibility of professional development, while more than half of respondents $(53.9 \%)$ were satisfied with the support they receive from superiors. The high level of dissatisfaction among employees was found in relation to financial compensation for their work, as much as $70.5 \%$ (Table 3).

Employees evaluated the exhaustion associated with the work through physical and emotional exhaustion associated with the job, as well as feeling tired just thinking about work. The results showed that almost half of employees (43.2\%) felt emotional exhaustion often or always after work, and the situation was almost identical in terms of perception of physical exhaustion after work $(42.4 \%)$. Exhaustion at the thought of going to work was Table 1. Distribution of employees (expressed in percentages) according to the general job satisfaction and profile of employees

\begin{tabular}{|l|c|c|c|c|c|}
\hline Satisfaction & $\begin{array}{c}\text { Health care } \\
\text { workers }\end{array}$ & $\begin{array}{c}\text { Health } \\
\text { associates }\end{array}$ & $\begin{array}{c}\text { Administrative } \\
\text { workers }\end{array}$ & $\begin{array}{c}\text { Technical } \\
\text { workers }\end{array}$ & Total \\
\hline Very dissatisfied & 7.1 & 20.5 & 8.4 & 7.7 & 7.7 \\
\hline Dissatisfied & 13.8 & 12.8 & 15.7 & 23.1 & 14.5 \\
\hline $\begin{array}{l}\text { Neither satisfied nor } \\
\text { dissatisfied }\end{array}$ & 37.4 & 30.8 & 32.5 & 32.1 & 36.4 \\
\hline Satisfied & 34.4 & 30.8 & 38.6 & 23.1 & 33.8 \\
\hline Very satisfied & 7.4 & 5.1 & 4.8 & 14.1 & 7.6 \\
\hline Total & 100 & 100 & 100 & 100 & 100 \\
\hline
\end{tabular}

Table 2. Satisfaction with interpersonal relations and cooperation with colleagues

\begin{tabular}{|l|c|c|}
\hline Grade & Interpersonal relationships & Cooperation with colleagues \\
\hline & $\mathrm{n}(\%)$ & $\mathrm{n}(\%)$ \\
\hline Very dissatisfied & $87(7.8)$ & $41(3.7)$ \\
\hline Dissatisfied & $143(12.8)$ & $56(5.1)$ \\
\hline Neither satisfied nor dissatisfied & $308(27.6)$ & $230(20.8)$ \\
\hline Satisfied & $440(39.4)$ & $582(52.6)$ \\
\hline Very satisfied & $138(12.4)$ & $198(17.9)$ \\
\hline Total & $1116(100)$ & $1107(100)$ \\
\hline
\end{tabular}

Table 3. Satisfaction with opportunities for professional development, support of superiors and financial compensation for work

\begin{tabular}{|l|c|c|c|}
\hline Grade & $\begin{array}{c}\text { Opportunities for professional } \\
\text { development }\end{array}$ & $\begin{array}{c}\text { Support by } \\
\text { superiors }\end{array}$ & $\begin{array}{c}\text { Financial } \\
\text { compensation }\end{array}$ \\
\hline & $\mathrm{n}(\%)$ & $\mathrm{n}(\%)$ & $\mathrm{n}(\%)$ \\
\hline Very dissatisfied & $97(8.7)$ & $87(7.7)$ & $466(41.3)$ \\
\hline Dissatisfied & $225(20.1)$ & $153(13.5)$ & $361(32.0)$ \\
\hline $\begin{array}{l}\text { Neither satisfied nor } \\
\text { dissatisfied }\end{array}$ & $371(33.2)$ & $283(24.9)$ & $171(15.2)$ \\
\hline Satisfied & $354(31.7)$ & $467(41.1)$ & $91(8.1)$ \\
\hline Very satisfied & $70(6.3)$ & $145(12.8)$ & $38(3.4)$ \\
\hline Total & $1117(100)$ & $1135(100)$ & $1127(100)$ \\
\hline
\end{tabular}


felt often or always by every fourth employee (25.6\%) (Table 4). The comparison of job satisfaction in relation to the period of five years ago, indicated that it had not changed in two-fifths of the respondents (41\%), while $40.5 \%$ were more dissatisfied and $18.6 \%$ were more satisfied than five years ago.

Only slightly more than one third of employees $(37.3 \%)$ were not thinking about changing jobs in the next five years, and among those who would change the job, a little less than half (46.9\%) would remain in the state health sector, $5.4 \%$ would like to move into the private sector and $10.4 \%$ would seek new jobs outside of health care. In doing so, the plans for the next five-year period differed significantly in relation to the occupation of respondents $\left(\chi^{2}=23.071, \mathrm{df}=9, \mathrm{p}=0.006\right)$ (Figure 2). Taking all this into account, $22.4 \%$ of the respondents were dissatisfied about their current work, and 41.2\% were satisfied (Figure 3).

The results of logistic regression showed that the following factors had a statistically significant impact on the assessment of job satisfaction: adequacy of work equipment, possibility of professional development, support by superiors, comparison of satisfaction 5 years ago and now (Table 5).

\section{DISCUSSION}

Employee satisfaction is a complex phenomenon (11). Many studies indicate a link between employee satisfaction, productivity and their commitment to work $(12,13)$. The health system and the provision of health care are specific and sensitive in relation to other spheres of work. Assessing and improving the quality implies a dynamic process, not only the control and maintenance of the achieved level of quality, because the required levels of quality in health care are shifting over time (7). The operational products of the health system and health employees are the health services whose quality is consequently associated with the pleasure and motivation of employees in health care (11). Of course, the

Table 4. Presence of emotional, physical exhaustion and fatigue at a thought of the job

\begin{tabular}{|l|c|c|c|}
\hline Responses & $\begin{array}{c}\text { Emotional exhaustion after } \\
\text { work }\end{array}$ & $\begin{array}{c}\text { Physical exhaustion after } \\
\text { work }\end{array}$ & $\begin{array}{c}\text { Fatigue at the thought of } \\
\text { work }\end{array}$ \\
\hline No, never & $\mathrm{n}(\%)$ & $\mathrm{n}(\%)$ & $\mathrm{n}(\%)$ \\
\hline No, rarely & $108(12.1)$ & $88(9.7)$ & $225(25.8)$ \\
\hline $\begin{array}{l}\text { Yes, } \\
\text { sometimes }\end{array}$ & $113(12.6)$ & $135(14.9)$ & $204(23.4)$ \\
\hline Yes, often & $288(32.1)$ & $299(33.0)$ & $219(25.1)$ \\
\hline Yes, always & $235(26.2)$ & $215(23.8)$ & $128(14.7)$ \\
\hline Total & $152(17.0)$ & $168(18.6)$ & $95(10.9)$ \\
\hline
\end{tabular}

Table 5. The results of logistic regression analysis

\begin{tabular}{|l|c|c|c|c|c|c|}
\hline Independent variables & B & S.E. & Wald & Df & $p$ & Exp(B) \\
\hline Adequacy of work equipment & 0.663 & 0.202 & 10.828 & 1 & 0.001 & 1.941 \\
\hline Interpersonal relationships & 0.265 & 0.192 & 1.917 & 1 & 0.166 & 1.304 \\
\hline Possibility of professional development & 0.697 & 0.206 & 11.481 & 1 & 0.001 & 2.007 \\
\hline Financial compensation & 0.143 & 0.213 & 0.451 & 1 & 0.502 & 1.154 \\
\hline Support by superiors & 0.785 & 0.199 & 15.541 & 1 & 0.000 & 2.192 \\
\hline I feel emotionally exhausted after work & -0.377 & 0.227 & 2.766 & 1 & 0.096 & 0.686 \\
\hline I feel physically exhausted after work & 0.133 & 0.215 & 0.384 & 1 & 0.536 & 1.142 \\
\hline $\begin{array}{l}\text { I can feel fatigue at the thought that we should } \\
\text { go on with the job }\end{array}$ & -0.292 & 0.158 & 3.417 & 1 & 0.065 & 0.747 \\
\hline $\begin{array}{l}\text { Comparison of satisfaction of 5 years ago and } \\
\text { now }\end{array}$ & -0.963 & 0.262 & 13.456 & 1 & 0.000 & 0.382 \\
\hline Plans about changing jobs & 0.042 & 0.120 & 0.125 & 1 & 0.723 & 1.043 \\
\hline $\begin{array}{l}\text { Are you currently doing any of the managerial } \\
\text { functions }\end{array}$ & -0.261 & 0.525 & 0.248 & 1 & 0.619 & 0.770 \\
\hline Profession & 0.306 & 0.224 & 1.871 & 1 & 0.171 & 0.736 \\
\hline Constant & -2.284 & 1.826 & 1.569 & 1 & 0.210 & 0.102 \\
\hline
\end{tabular}


satisfaction of health care personnel is very important, because it is associated with patient satisfaction and quality of health services (14).

The results of our study show that two-fifths of employees are satisfied with the work that they are performing, while every fifth respondent is dissatisfied. Results relating to communication (interpersonal relationships, collaboration with colleagues) indicate greater satisfaction with these aspects of the work in relation to others. More than two thirds of our examinees are satisfied with working with colleagues, which confirms that promotion of teamwork and good interpersonal communication, which has been particularly insisted on for years, are giving their results in the context of satisfaction.

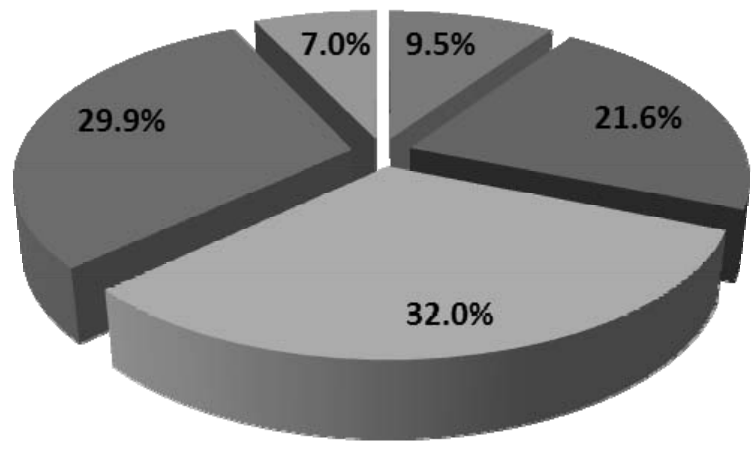

Very dissatisfied

Dissatisfied

Neither satisfied nor dissatisfied

- Satisfied

very satisfied

Figure 1. Satisfaction with work equipment

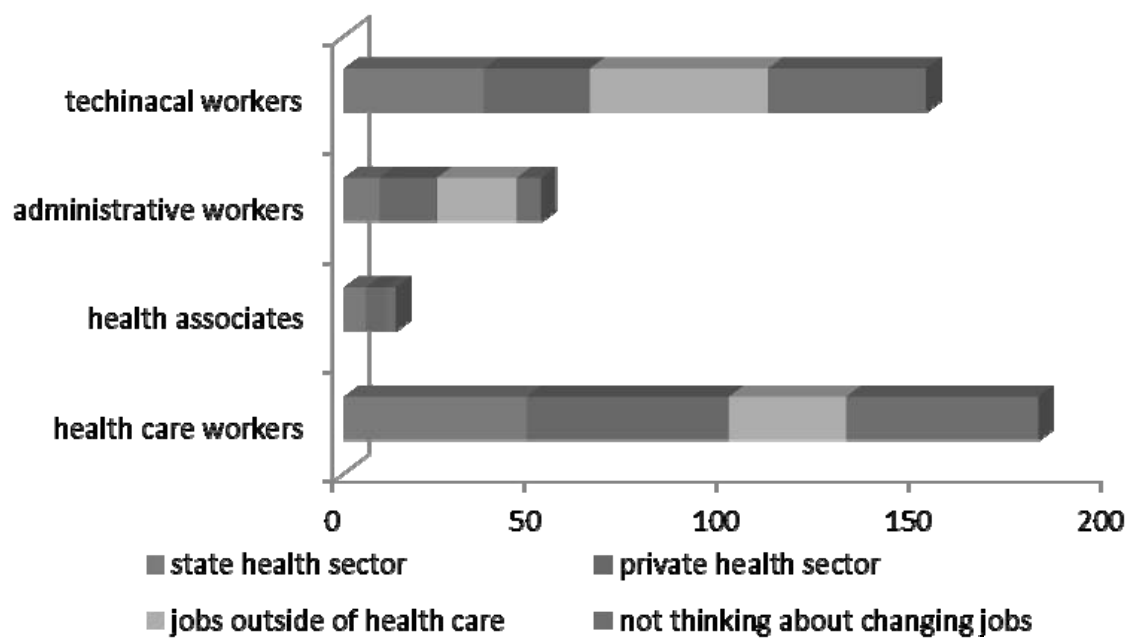

Figure 2. Plans related to the change of work over the next five years in relation to the occupation

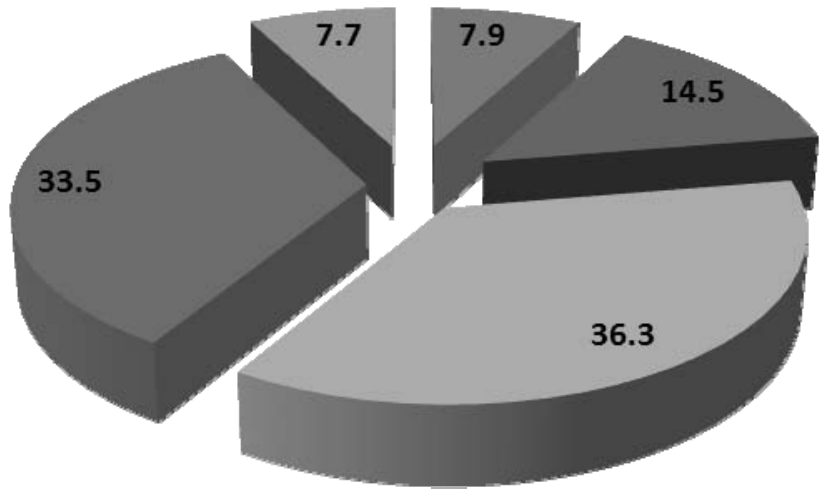

- Very dissatisfied

Dissatisfied

Neither satisfied nor dissatisfied

- Satisfied

Very satisfied

Figure 3. Job satisfaction (\%) 
As motivation is always at the center of employee satisfaction, we analyzed their motivation to conduct business in an appropriate manner, by assessing employees' satisfaction (15). Employee motivation was observed in the context of opportunities for professional development, support by superiors and through financial compensation for their work. Financial compensation for the work, or more precisely the level of satisfaction by this factor, has drastically decreased comparing it with the rest of the examined aspects. This is not surprising considering the economic situation in the country. Two thirds of employees in health institutions in Sumadija district are dissatisfied with their monthly salary, while only one in ten respondents is satisfied with his salary. There is also a high level of dissatisfaction with work equipment in service, where a little less than a third of those surveyed are dissatisfied and very dissatisfied. Physical and emotional exhaustion associated with the job is felt by almost every second employee, while the feeling of tiredness at the thought of work is present in every fourth respondent.

Motivation and satisfaction of employees are the key tasks of modern human resource management, because it is only by establishing a quality motivation system that a higher productivity can be achieved. The task of managers is to understand human complexity and uniqueness, and that depending on the specific characteristics of individuals and groups, as well as the specifics of the circumstances in which they are operating, select and implement tangible and intangible methods for motivating employees. An organization achieves its goals only if its employees and managers are motivated to achieve their tasks (16).

In conclusion, slightly less than a half of employees in health institutions of the Republic of Serbia are satisfied (satisfied and very satisfied) with the work they perform. The experience of work and satisfaction by employees indicates the need for placing the satisfaction of employees on the priority place in the process of improving the quality of the health care system. The management of health care facilities must be engaged to undertake measures to improve employees' satisfaction, especially in the sphere of workers information, developing teamwork, improving work organization and proper scheduling of tasks. Management of health care institutions must find ways to increase the satisfaction and engagement of employees.

\section{REFERENCES}

1. Khamlub S, Harun-Or-Rashid M, Sarker MA, Hirosawa T, Outavong P, Sakamoto J. Job satisfaction of health-care workers at health centers in Vientiane Capital and Bolikhamsai Province, Lao PDR. Nagoya J Med Sci 2013; 75: 233-41.
2. Nikić D, Aranđelović M, Nikolic M, Stankovic A. Job satisfaction in health care workers. Acta medica Medianae 2008; 47: 9-12.

3. Bhatnagar K, Srivastava K. Job satisfaction in healthcare organizations. Ind Psychiatry J 2012; 21: 75-8.

4. Buciuniene I, Blazeviciene A, and Bliudziute F. Health care reform and job satisfaction of primary health care physicians in Lithuania BMC Fam Pract 2005; 6: 10.

5. Kumar P, Khan AM, Inder D, Mehra A. A comparative study of job satisfaction among regular and staff on contract in the primary health care system in Delhi, India. J Family Community Med 2014; 21: 112-8.

6. Dieleman M, Toonen J, Touré H, Martineau T. The match between motivation and performance management of health sector workers in Mali. Hum Resour Health 2006;4: 2.

7. West E. Management matters: the link between hospital organization and quality of patient care. Qual Health Care 2001; 10: 40-8.

8. Syptak JM, Marsland DW, Ulmer D. Job satisfaction: putting theory into practice. Fam Pract Manag 1999; 6: 26-30.

9. Haas JS, Cook EF, Puopolo AL, Burstin HR, Cleary PD, Brennan TA. Is the professional satisfaction of general internists associated with patient satisfaction? J Gen Intern Med 2000; 15: 122-8.

10. Comparative analysis of satisfaction of employees in state institutions of the Republic of Serbia in 2013 surveys. Belgrade. Institute of Public Health of Serbia, 2014. (www.batut.org.rs) (in Serbian)

11. Peltier J, Dahl A. The relationship between employee satisfaction and hospital patient experiences. Forum. Wisconsin: University of Wisconsin; 2009.

12. Pierce JL, Dunham RB, Blackburn RS. Effects of communication direction on job performance and satisfaction: a moderated regression analysis. JBTC 2000; 22: 223-40.

13. Griffin RW. Objective and social factors as determinants of task perceptions and responses: an integrated perspective and empirical investigation. Acad Manag J 1987; 39: 501-23.

14. Rival PE, Elixhauser A, Christiansen CL, et al. Testing the association between patient safety indicators and hospital structural characteristics in VA and nonfederal hospitals. Med Care Res Rev 2010; 67: 321-41.

15. Paul F. Health worker motivation and the role of performance based finance systems in Africa: a qualitative study on health worker motivation and the Rwandan Performance based finance initiative in districts hospitals. London: Working Paper Series 2009, (08-96): 4-5.

16. Jokić S, Bradonjić D, Ćoćkalo D. Motivation and motivational factors of employees. Megatrend revija 2012; 9: 201-16. 